\title{
Diversity and local status of bryophytes in Mai pokhari of Ilam district, east Nepal
}

\author{
Nirmala Pradhan ${ }^{1} \bowtie$ and Ragnhild Heimstad ${ }^{2}$ \\ ${ }^{1}$ Natural History Museum, Tribhuvan University, Swayambhu, Kathmandu, Nepal \\ ${ }^{2}$ Multiconsult ASA, Nedre Skoeyenvei 2, 0276 Osio, Norway \\ bryonep@yahoo.com
}

\begin{abstract}
Bryophytes in Mai Pokhari area of llam District, east Nepal was studied in September 2013 to investigate species diversity and status. A total of 42 bryophytes were compiled occurrence status. Plagiochila exigua (Taylor) Taylor, Dicranella setifera (Mitt.) A. Jaeger, Trematodon kurzii Hampe ex Gangulee and Pseudobarbella niitakayamensis Nog. recorded in this study are new additions to Nepal. Wet and damp areas around this lake are suitable habitats for the sporophytic growth of man+y bryophyte species.
\end{abstract}

Keywords: sporophyte, new record, habitat, lake, Ilam

\section{INTRODUCTION}

Bryophytes, non-flowering plants, are widely distributed at various geographical localities in the tropical to the Himalayan bioclimatic zones of Nepal. The gametophyte stage of this group of plants shows dominancy in their life cycle while the sporophyte stage is short lived showing distinct alternation of generations. The unbranched sporophyte produces a single terminal sporangium bearing spores in it. In average, the size of this plant varies from $0.5 \mathrm{~mm}$ to 166 cm long (Pradhan, 2015).

The diverse distribution patterns of bryophytes are mainly due to their greater dispersal capacity through the minute spores present in their capsules. The elaters in Hepaticae and peristome teeth in Musci play significant role for the dispersal of spores. The favorable conditions of environment like humidity and precipitation contribute for the luxuriant growth of this group of plants in nature. In Nepal, their distribution pattern and diversity change has remarkably been displayed from the lowest elevation of $62 \mathrm{~m}$ to 6,500 $\mathrm{m}$ in the Himalayan Zone (Pradhan, 2015). The species richness of this plant is highest in the temperate region which remains a transition zone for the subtropical and subalpine species. Most of the endemic species have been recorded in this region (Grau et al., 2007).

In Nepal, bryophytes have been studied mostly from Central Nepal. Few studies on bryophytes in east Nepal are available. Thirty-three moss species were reported from the entire Ilam district (Higuchi \& Takaki, 1990). Ilam district is important as it has Mai Pokhari lake from where Sphagnum nepalensis (Sphagnaceae), an endemic peat moss floating on the surface of the lake water was reported. Compared to the reports of 10 chlorophacean algae, 30 pteridophytes, 8 gymnosperms, and 197 angiosperms (monocots, 30 pteridophytes (Rai, 2009; Bhattarai, 2073), only 3 bryophytes (Marchantia sp., Sphagnum nepalense and Funaria 
sp.) were reported from Maipokhari Ramsar site by Bhattarai (2073). To enrich knowledge on bryophytes of this important Ramsar site, a study has been carried out to list the species diversity and status.

\section{MATERIALS AND METHODS}

\section{Study area}

Mai Pokhari, a small temperate lake with an area of 90 hectare is situated at 2,240 m of elevation in Ilam district of east Nepal. Natural springs and rains are the main water sources for this lake system (DPR, 2015). Situated at its geographical stand of $27^{\circ} 25^{\prime} \mathrm{N}$ and $87^{\circ} 55^{\prime} \mathrm{E}$, this lake was registered as Ramsar Site in October 8, 2008. The main flora around this lake includes Schima wallichii, Castanopsis, Pinus, Rhododendron species etc and many epiphytic orchids.

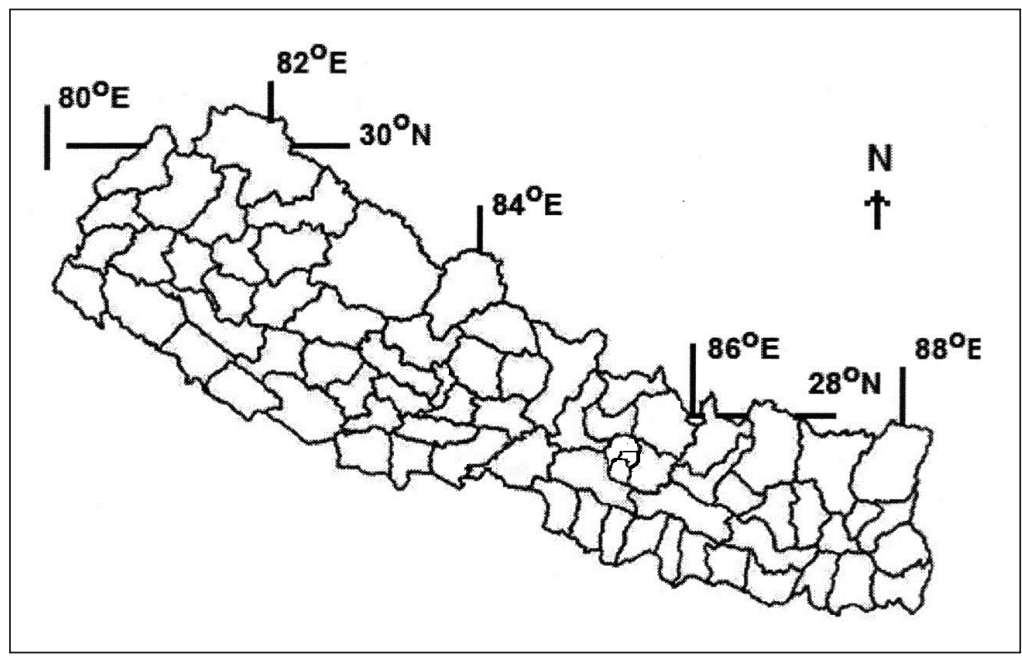

FIG. 1. Circular mark in the Map of Nepal indicates the study area.

Specimens of bryophytes were collected in the month of September of 2013 from different habitats like shaded marshy earth, acidic soil, exposed ground, stone edges, temple wall, tree canopy and tree trunks of Maipokhari, llam. A simple pocket knife was used to collect specimens at different habitat types. Hand lens with magnifying power 5-40 x was used for field identification. Local status of each collected specimens were noted as common, fairly common, and rare.

All the collected specimens were identified with the help of relevant literatures (such as Eddy, 1988, 1990 1996; Gangulee, 1969-1980; Chopra, 1975; Pradhan, 2000; So, 1995; Zyu \& So, 1996; Smith, 1996; Yang, 2011) at the Natural History Museum using compound microscope of 5-40 magnifying power with eye-piece 15 and ocular micrometer for measuring cell size, spores and other microscopic organs. The magnifying and microscopic photographs were also taken in the laboratory (fig.4, 5).

Brummitt \& Powell (1992) and W3TROPICOS were followed for scientific names and author 
citations. Identified specimens were preserved in paper packets with well label field data and deposited at the Natural History Museum, Kathmandu with accession numbers of museum for future references.

\section{RESULTS AND DISCUSSION}

\section{Species diversity}

A total of 42 species of bryophytes belonging to two classes viz. Hepaticae and Musci were recorded from Maipokhari, Ilam, Nepal (appendix I). Of the recorded species, class Hepaticae was represented by 13 species belonging to 10 genera, 10 families and 3 orders. Class Musci showed higher diversity with 29 species under 28 genera, 19 families and 10 orders. Of the recorded Hepaticae, the order Jungermanniales included eight species with six families, Marchantiales represented three species of two families and Metzgeriales with two species in two families. The order Hypnobryales of Musci had high species diversity with the record of nine species under six families but orders like Hookeriales, Orthotrichales, Polytrichales and Sphagnales represented single species of one family only. Other orders like Dicranales represented three species of a single family, Eubryales with four species in two families, Fissidentales with two species in one family, Isobryales with four species in three families and Pottiales with three species in two families only (fig. 2, 3). Of the total genera, only three (Plagiochila, Marchantia and Fissidens) contained two or three species. Out of the total recorded species, Plagiochila exigua (Taylot) Taylor of Hepaticae and Dicranella setifera (Mitt.) A. Jaeger, Trematodon kurzii Hampe ex Gangulee and Pseudobarbella niitakayamensis Nog. of Musci were not reported previously from Nepal. Epiphytic bryophytes like Frullania tamariscii, Plagiochila semidecurrens, Bazzania tridens, Trachypodopsis serrulata, Syrrhopodon gardneri, Entodon rubicundus, etc. were also found in this lake area.

\section{Status of bryophytes}

Of the total records, nine species were found rare, one endemic, 16 species were fairly common and rest were common species considering their local status. One is typed specimen and four species were recorded new to country's list. Dicranella setifera and Trematodon kurzii though common were not recorded before.

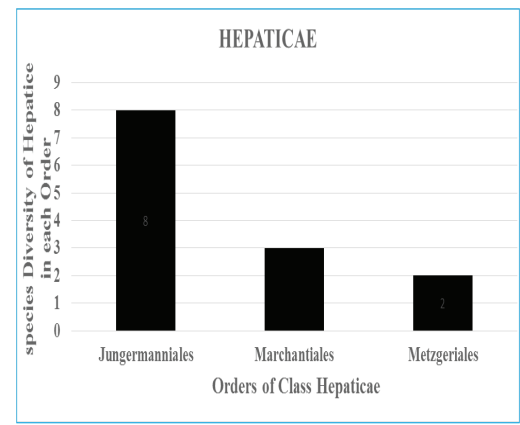

FIG. 2. Species diversity in the orders of Hepaticae class.

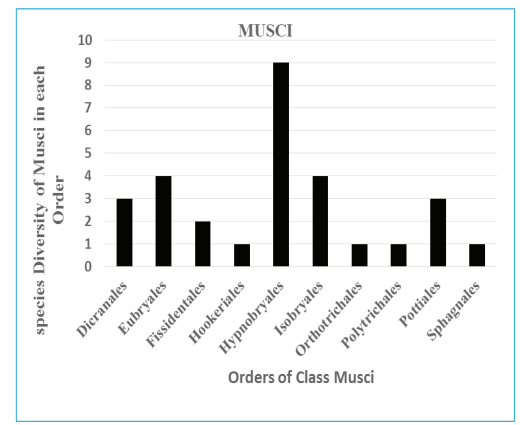

FIG. 3. Species diversity in the orders of Musci class. 


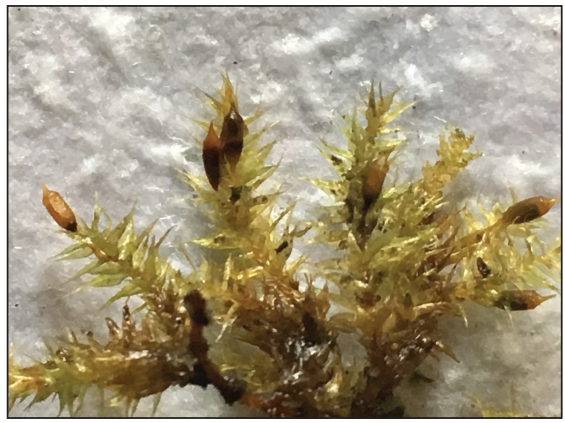

FIG. 4. Pseudobarbella niitakayamensis Nog.

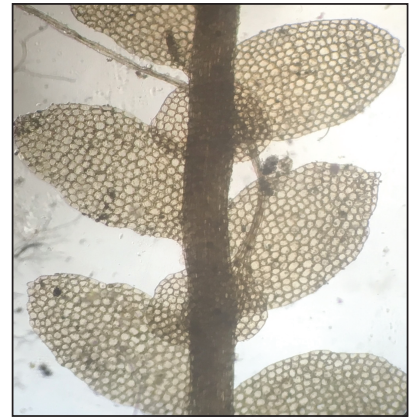

FIG. 5. Metacalypogeia alternifolia (Nees) Grolle.

The spread of invasive species, unmanaged constructions and human settlements are imposing direct impact on the habitat of many bryofloral species in this part. This has been observed that the Sphagnum nepalensis is losing its status as compared to previous study made in this lake (Pradhan, 2009).

Very little information is available on other aspects of this lake. Rai (2011) in his study revealed the lentic environment of Mai Pokhari lake where macro invertebrates were sampled periodically in two different years. This revealed the occurrence of good natural condition of this lake as indicated by the presence of higher bottom fauna. Department of Plant Resources (DPR, 2015) with an objective to promote tourism in this part has established an educational and plant research center which includes the entire Mai Pokhari forest garden.

Previous record of Plagiochila exigua was made by Long and Grolle (1990) in Bhutan. Higuchi and Takaki (1990) provided a list of 36 moss species of the entire llam district which covered the elevations of $1030-2000 \mathrm{~m}$.

\section{ACKNOWLEDGEMENTS}

We are thankful to Yogendra Man Shrestha, Assistant Campus Chief of Mahendra Ratna Multiple College for logistic support for the field and Prof. Dr. Dharma Raj Dangol, Natural History Museum, for his valuable suggestions to prepare this manuscript.

\section{REFERENCES}

BHATTARAI, K R (2073) Maipokhari kshetraka banaspatiharu (English translation Plants of Maipokhari areas). Kathmandu: Department of Plant Resources.

BRUMMITT, R K; POWELL, C B (1992) Authors of plant names. Royal Botanic Garden, Kew, UK.

CHOPRA, R (1975) Taxonomy of Indian mosses. Bot. Monograph 10, Pubs. \& Inf. Directorate; New Delhi, India.

DEGUCHI, H; HIGUCHI, M (1992) Mosses from Nepal collected by Botanical expeditions of National Science Museum, Tokyo. 2. Grimmiacae Mem Fac Sci Kochi Univ ser D (Biol) 13: 5-8.

DPR (2016). http://dpr.gov.np/gardens/maipokhari_botanical_garden,_ilam.

DPR (2015) Mai Pokhari botanical garden. Department of Plant Resources, Ministry of Forest Resources 
and Soil Conservation. Retrieved10 November 2015.

EDDY, A (1988) A handbook of Malaysian mosses I. London: British Museum (Natural History). EDDY, A (1990) A handbook of Malaysian mosses II. London: British Museum (Natural History). EDDY, A (1996) A handbook of Malaysian mosses III. London: British Museum (Natural History). GANGULEE, H C (1969-1980) Mosses of eastern India and adjacent regions. Fasc.1-8. Published by the Author; Calcutta, India; pp 1-2145.

GRAU, O; J A; GRYTNES; BIRKS, H J B (2007) A comparison of altitudinal species richness patterns of bryophytes with other plant groups in Nepal, Central Himalaya. Journal of Biogeography 34: 1907-1915. HIGUCHI, M; TAKAKI, N (1990) Mosses from Nepal collected by botanical expedition of National Science Museum, Tokyo. In WATANABE, M; MALLA, S B (eds) Cryptogams of the Himalayas, central and eastern Nepal 2: 121-161.

https://en.wikipedia.org/wiki/List_of_club-mosses_and_mosses_of_Montana

LONG, D G; GROLLE, R (1990) Hepaticae of Bhutan II. Journ Hattori Bot Lab 68: 381-440.

PRADHAN, N (2009) Important of Sphagnum moss in environment, society and industry Hamro Sampada, 9(1): 72-73 (B.S. 2066) (in Nepali).

PRADHAN, N (2000) Materials for a checklist of bryophytes of Nepal. The Natural History Museum (BM), London, UK.

PRADHAN, N (2015) Bryophytes of Nepal. In JHA, P K; RAJBHANDARY, S (eds) Frontier's of botany. Central Department of Botany, Tribhuvan University, Nepal; pp 100-123.

PRADHAN, N (2014) Three new records of Jungermannia species (Hepaticae, Jungermanniales) from Nepal. International Journal of Environment 3(1): 85-92.

RAI, K R (2011) Comparative studies on lentic environment of Mai Pokhari, Ilam and Kechana jheel wetland ecosystems, Jhapa, Nepal (with reference to bottom dwelling fauna). Nepalese Journal of Biosciences 1: 32-36.

RAI, S K (2009) Some chlorophycean algae from Maipokhari lake, Ilam, east Nepal. Journal of Natural History Museum 24: 1-8.

SMITH, A J E (1996) Liverworts of Britain and Ireland. Cambridge University Press, Cambridge, UK.

SO, M L (1995) Mosses and liverworts of Hong Kong I. Heavenly People Depot, Hong Kong.

$\mathrm{W}^{3}$ TROPICOS www.tropicos.org.

YANG, J D (2011) Liverworts and hornworts of Taiwan II. National Science Council, Taiwan.

ZYU, R L; SO, M L (1996) Mosses and liverworts of Hong Kong II. Heavenly People Depot, Hong Kong. 


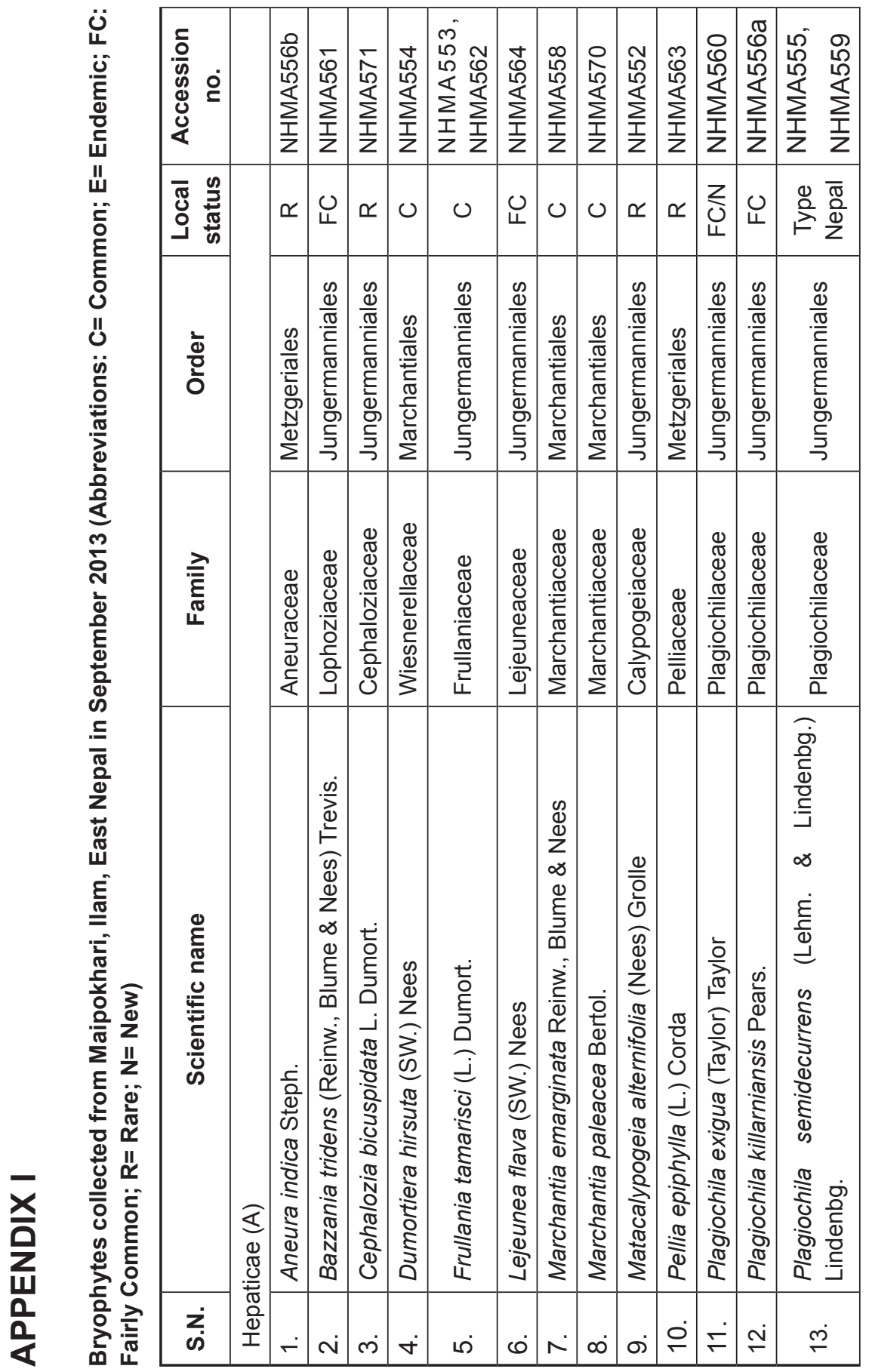


Pradhan and Heimstad: Diversity and local status of bryophytes

\begin{tabular}{|c|c|c|c|c|c|c|c|c|c|c|c|c|c|c|c|c|c|c|c|c|}
\hline & 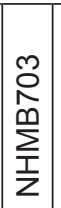 & 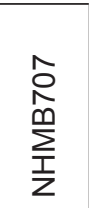 & 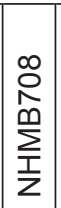 & 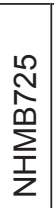 & 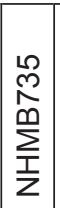 & 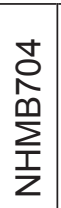 & 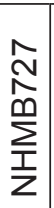 & 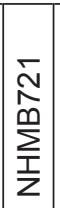 & $\begin{array}{l}\stackrel{m}{\Sigma} \\
\stackrel{m}{\Sigma} \\
\frac{1}{z}\end{array}$ & 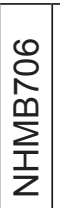 & 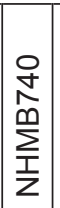 & $\begin{array}{c}\text { O } \\
\mathbf{N} \\
\text { m } \\
\frac{1}{z} \\
\frac{1}{z}\end{array}$ & 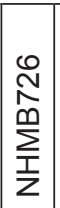 & $\left|\begin{array}{l}\Omega \\
\Sigma \\
\underline{m} \\
\frac{1}{\Sigma} \\
\Sigma\end{array}\right|$ & 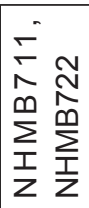 & 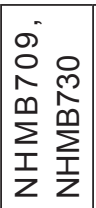 & 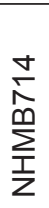 & 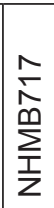 & 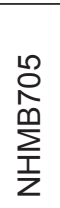 & 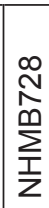 \\
\hline & $\begin{array}{l}0 \\
\Psi\end{array}$ & 0 & 0 & 0 & 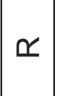 & $\propto$ & 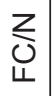 & $\begin{array}{l}0 \\
\longleftarrow\end{array}$ & $\begin{array}{l}0 \\
\square\end{array}$ & 0 & 0 & $\begin{array}{l}\cup \\
\longleftarrow\end{array}$ & 0 & $\begin{array}{l}\cup \\
\longleftarrow\end{array}$ & U & U & 0 & U & $\underset{\alpha}{z}$ & U \\
\hline & 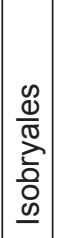 & $\begin{array}{l}\frac{\mathscr{d}}{\frac{0}{N}} \\
\frac{2}{0} \\
\stackrel{0}{\vec{n}}\end{array}$ & 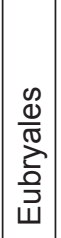 & 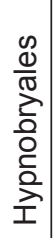 & 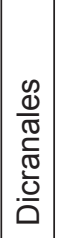 & 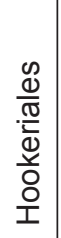 & 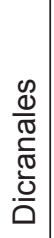 & 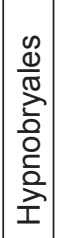 & 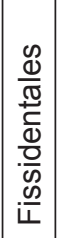 & 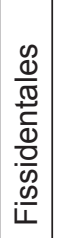 & 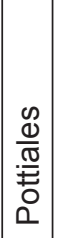 & 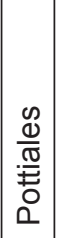 & 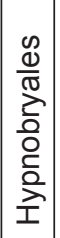 & $\begin{array}{l}0 \\
\frac{0}{0} \\
\frac{0}{0} \\
\frac{2}{2} \\
\frac{0}{0} \\
\frac{0}{2} \\
\frac{2}{2} \\
\text { 1. }\end{array}$ & 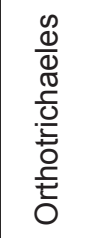 & $\begin{array}{l}\frac{d}{d} \\
\frac{d}{2} \\
\frac{0}{2} \\
w\end{array}$ & $\begin{array}{l}0 \\
\frac{0}{\pi} \\
\frac{10}{2} \\
\frac{0}{0} \\
\frac{2}{2} \\
\frac{2}{1}\end{array}$ & $\begin{array}{l}0 \\
\frac{0}{0} \\
\frac{0}{0} \\
.0 \\
\frac{2}{2} \\
\frac{2}{0} \\
0\end{array}$ & 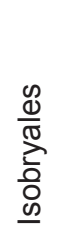 & 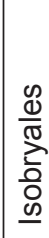 \\
\hline & 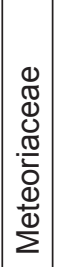 & 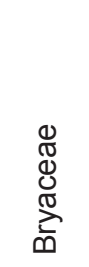 & 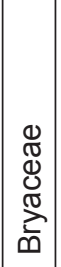 & 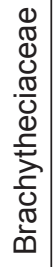 & 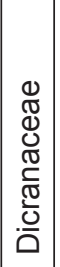 & 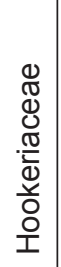 & $\begin{array}{l}\mathbb{0} \\
\mathbb{N} \\
0 \\
\frac{0}{0} \\
\frac{\pi}{0} \\
\frac{\pi}{0} \\
\frac{0}{0}\end{array}$ & 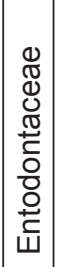 & 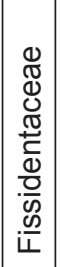 & 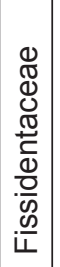 & 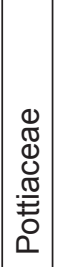 & 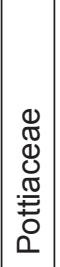 & 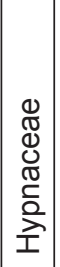 & 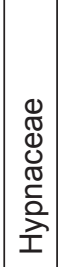 & 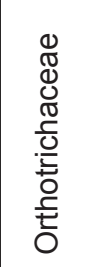 & 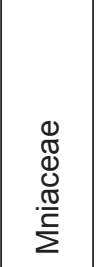 & 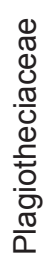 & $\begin{array}{l}0 \\
\mathbb{0} \\
0 \\
0 \\
0 \\
\frac{0}{U} \\
.0 \\
.0 \\
\frac{1}{2} \\
0 \\
0 \\
0\end{array}$ & 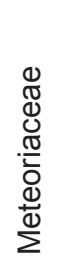 & 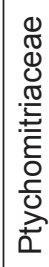 \\
\hline$\tilde{\underline{m}}$ & 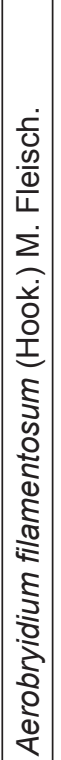 & 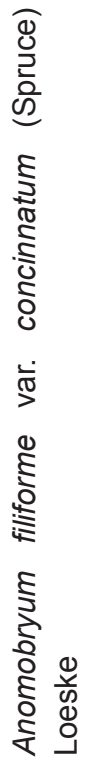 & 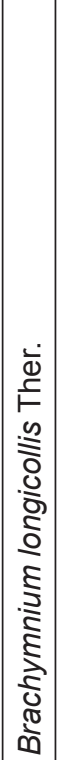 & 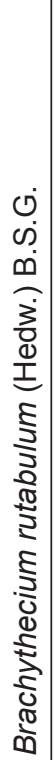 & 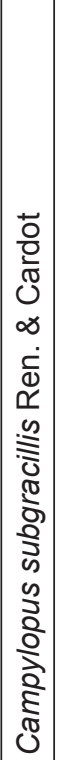 & 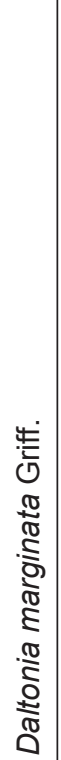 & 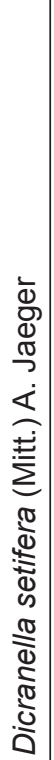 & 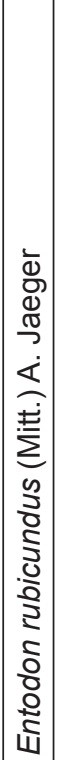 & 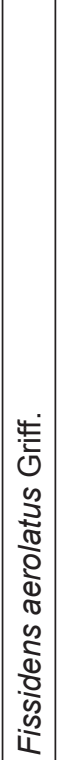 & 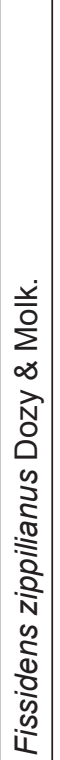 & 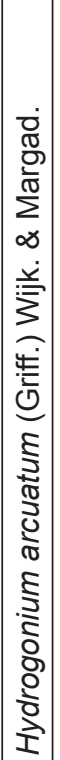 & 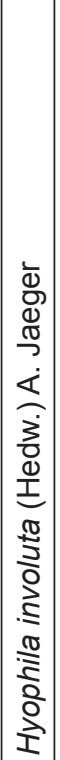 & 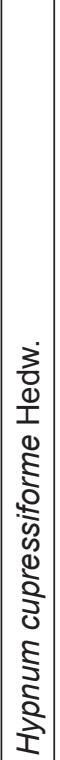 & 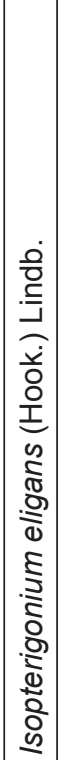 & 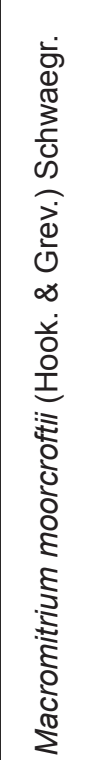 & 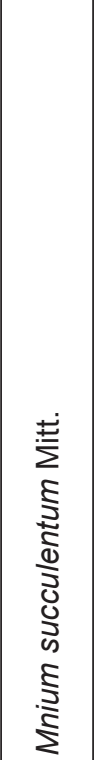 & 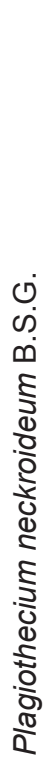 & 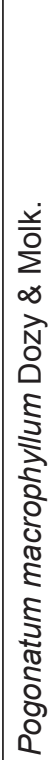 & 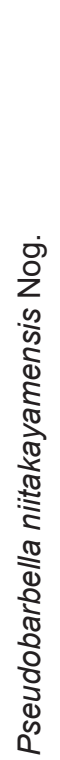 & 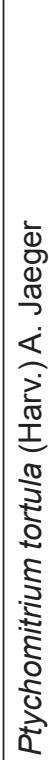 \\
\hline$\stackrel{2}{\Sigma}^{2}$ & 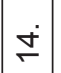 & $\stackrel{n}{\leftarrow}$ & $\stackrel{0}{\sigma}$ & 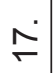 & $\stackrel{\infty}{-}$ & $\stackrel{\sigma}{\square}$ & $\sim$ & $\bar{\sim}$ & N & $\widetilde{N}$ & $\stackrel{\mathbf{N}}{\mathbf{N}}$ & $\stackrel{\sim}{N}$ & $\stackrel{\sim}{N}$ & 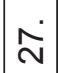 & $\underset{v}{ }$ & N & m & $\bar{m}$ & లి & m \\
\hline
\end{tabular}




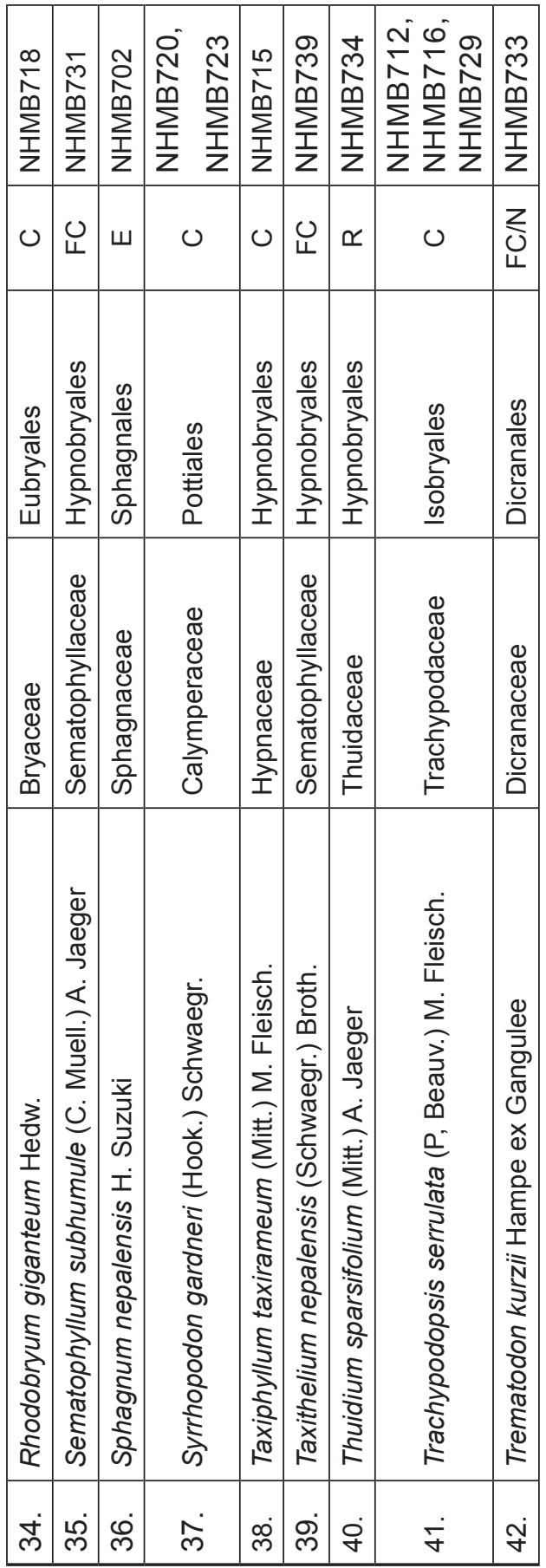

